\section{The relation between rectal and brain temperatures following hypothermia*}

\author{
DONALD J LEWIS \\ University of Southern California, Los Angeles, Calif. 90007 \\ FLORENCE JACKSON \\ Rutgers University, New Brunswick, N.J. 08903 \\ RALPH R. MILLER \\ Brooklyn College of CUNY, Brooklyn, N.Y. 11210 \\ and \\ JAMES R. MISANIN \\ Susquehanna University, Selinsgrove, $\mathrm{Pa}, 17870$
}

The core temperatures and brain temperatures of rats were simultaneously tracked. Ice water immersion produces almost as marked a decrease in brain temperature as in core temperature. During the unaided recovery of normal temperatures following hypothermia, rectal and brain temperatures follow a parallel course.

It has long been held (Gerard, 1963) that a rapid cooling of the brain following a learning experience produces an amnesia for that experience. The clearest evidence for this belief is that of Riccio, Hodges, \& Randall (1968), who show that the extent of the amnesia is a function of the time between learning and the cooling. Beitel \& Porter (1968) determined duration of cooling to be an effective variable, and Riccio \& Stikes (1969) found that prior cooling does not have a proactive effect upon learning. In these studies temperature reduction was obtained by placing the rat in a cold environment. The temperature measurements were rectal, and it was assumed that there was a relationship between the core temperature measured by this technique and brain temperature. Because there are many mechanisms that protect the brain from bodily disturbances, it is not a foreordained fact that brain temperatures will follow body temperatures. In this study, it was our purpose to determine the extent to which brain temperatures could be reduced by cooling the body.

\section{SUBJECTS}

The Ss were four male Sprague-Dawley rats (Madison, Wis.), 95 days old and weighing $320-330 \mathrm{~g}$. APPARATUS

Brain temperature was measured with a 36-ga copper-constantan nylon-insulated thermocouple (C-V Instrument Co., Wallingford, Conn.) positioned inside the tip of a 1-in. 21-ga hubless hypodermic needle that was inserted into a stainless steel reentrant tube (Plastic Products, Roanoke, Va.) permanently implanted

* This research was supported by Grant MG 15777 from the National Institutes of Health, Public Health Service. in the brain. Thermopotentials were amplified and recorded on a Beckman Offner Type $R$ dynograph (Beckman A-C coupler Type 9806A). The thermocouple was tested in a water bath at various temperatures twice before and once after the measurement of brain temperature in each animal. Over a range of $19.0^{\circ}-37.0^{\circ} \mathrm{C}$, accuracy of calibration was $\pm .15^{\circ} \mathrm{C}$

For the periodic measurement of core temperature, a probe from a Yellowsprings telethermometer was used, inserted rectally to a depth of $6 \mathrm{~cm}$.

The immersion apparatus was a Plexiglas enclosure $4 \frac{1}{2} \times 7$ in. at the base and $14 \frac{1}{2} \mathrm{in}$. in height, open at top and bottom, placed in a circular plastic pail. Ice cubes were placed in the pail around the enclosure, and ice water was added to bring the level to $6 \frac{1}{2}$ in. PROCEDURE

Immediately prior to immersion in ice water, a single measure of rectal temperature was taken and a 10-min record of brain temperature was obtained with the tips of the probes within $1 \mathrm{~mm}$ of the placement: $2.6 \mathrm{~A}$, $5.0 \mathrm{~L},-1.5 \mathrm{H}$. In individual brains, the correspondence between left and right probe tips was $\leqslant 0.5 \mathrm{~mm}$. Then a cap was placed over the implant and the rat was immersed for $11-12 \mathrm{~min}$ in the ice water $\left(4.0^{\circ}-5.0^{\circ} \mathrm{C}\right)$. After initial movements about the enclosure and small jumps, Ss were observed to spend the major portion of the time standing with their forepaws against a wall of the enclosure and their heads and shoulders above water. At the end of the immersion period, the $S$ was wiped moderately dry and placed upon a surface covered with paper toweling in a $22^{\circ} \mathrm{C}$ room.

Rectal temperature was measured $1 \mathrm{~min}$ after removal from the water, and the continuous measurement of brain temperature was then initiated. Rectal temperature was again taken at the fifth minute of the postimmersion period and at 5 -min intervals thereafter. In two Ss, temperatures were followed through to recovery of normal levels.

\section{RESULTS}

Table 1 shows rectal and brain temperatures prior to immersion and the lowest temperatures reached following immersion. Before cooling, rectal temperatures were $3.2^{\circ} \mathrm{C}$ higher on the average than brain temperatures, but this difference was reduced to $1.4^{\circ} \mathrm{C}$ after cooling, since rectal temperatures decreased more $\left(15.0^{\circ} \cdot 16.7^{\circ} \mathrm{C}\right)$ than did brain temperatures $\left(12.8^{\circ}-14.7^{\circ} \mathrm{C}\right)$. Temperatures of the four animals were remarkably consistent. Rectal temperatures fell within a $1.0^{\circ} \mathrm{C}$ range both before and after cooling. Brain temperatures were within $1.8^{\circ} \mathrm{C}$ of each other before immersion, and afterwards fell to an almost uniform low of $21.8^{\circ}-22.0^{\circ} \mathrm{C}$, a spread of $0.2^{\circ} \mathrm{C}$.

Each record showed that a minimum temperature was reached during the first $5 \mathrm{~min}$ or so of the postimmersion period.

A representative record is shown in Fig. 1. In this animal (No. 3), rectal temperature fell from $38.7^{\circ} \mathrm{C}$ to postimmersion low of $23.7^{\circ} \mathrm{C}$, while brain temperature fell from $34.7^{\circ} \mathrm{C}$ to a low of $21.9^{\circ} \mathrm{C}$. In absolute terms, rectal temperature decreased more than did brain temperature $\left(15.0^{\circ} \mathrm{C}\right.$ vs $\left.12.8^{\circ} \mathrm{C}\right)$, though it remained higher than brain temperature throughout the

Table 1

Rectal and Brain Temperatures (in ${ }^{\circ} \mathrm{C}$ ) Before and After Ice Water Immersion

\begin{tabular}{|c|c|c|c|c|c|c|}
\hline \multirow[b]{2}{*}{ Rat } & \multicolumn{3}{|c|}{ Rectal } & \multicolumn{3}{|c|}{ Brain } \\
\hline & Before & After* & Decrease & Beforet & After* & Decrease \\
\hline 1 & 38.4 & 23.4 & 15.0 & 36.0 & 21.9 & 14.1 \\
\hline 2 & 39.4 & 22.7 & 16.7 & 35.3 & 22.0 & 13.3 \\
\hline 3 & 38.7 & 23.7 & 15.0 & 34.7 & 21.9 & 12.8 \\
\hline 4 & 38.7 & 23.3 & 15.4 & 36.5 & 21.8 & 14.7 \\
\hline Mean & 38.8 & 23.3 & 15.5 & 35.6 & 21.9 & 13.7 \\
\hline
\end{tabular}

* Minimum temperatures reached during postimmersion period + An average of the $10 \cdot \mathrm{min}$ record prior to immersion 


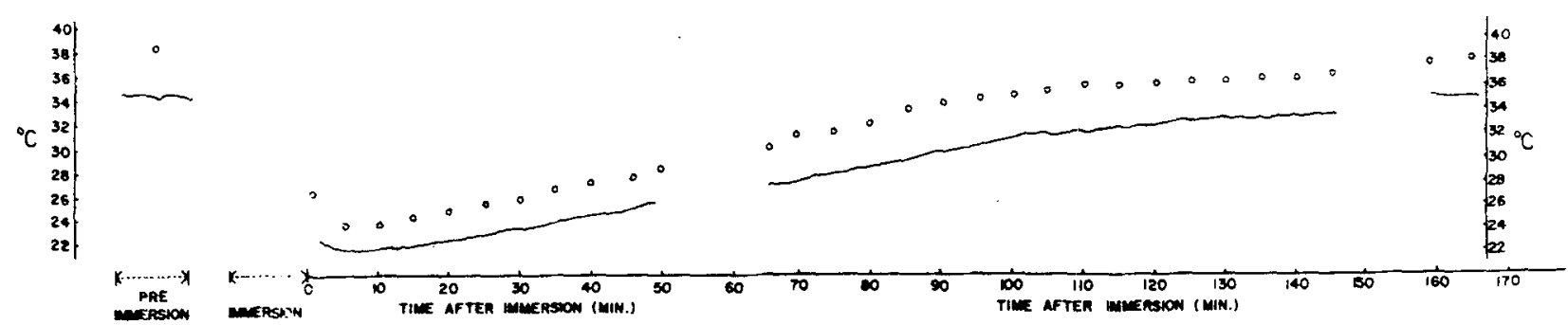

Fig. 1. Brain and rectal temperatures of a typical rat (No. 3 ) before and after immersion in ice water. The continuous record indicates brain temperature and the small circles represent periodic measurements of rectal temperature. See text for further explanation.

recovery period, the difference gradually changing from about $2.0^{\circ} \mathrm{C}$ to $3.0^{\circ} \mathrm{C}$. Approximately $21 / 2 \mathrm{~h}$ were required for complete recovery of normal temperature.

The interruption of the record at about $50 \mathrm{~min}$ was occasioned when the rat initiated strenuous grooming activity that endangered the positioning of the thermocouple. When grooming activity had subsided, the thermocouple was reinserted and measurement resumed. However, during this second period, the rat was held loosely supported in E's hand in order to prevent excessive motor activity while temperature measurements were taken. Comparison with other animals indicated no warming effect due to handling. The record was interrupted again at about $145 \mathrm{~min}$ to permit the rat to move about freely. This motor activity may have been essential for the final recovery shown subsequently in the graph, since for 20-30 min prior to this interruption temperatures had changed only slightly.

$$
\text { DISCUSSION }
$$

Ice water immersion appears to produce almost as great an effect upon the rat's brain temperature as upon its core temperature. The somewhat smaller decrease in brain temperature could be interpreted as indicating the operation of a protective mechanism, but it may reflect nothing more than the fact that the head was not in direct contact with the ice water and was therefore cooled only indirectly via blood and tissue conduction. The greater amount of water retained in the fur below the neck following removal from the ice bath would also have contributed to a greater cooling effect upon the trunk than upon the head.

\section{REFERENCES}

BEITEL R E \& PORTER, P. B. Deficits in retention and impairments in learning induced by severe hypothermia in mice. Journal of Comparative \& Physiological Psychology, 1968,66, 53-59.

$G$ E R D R W S y mosium Theoretical-experimental approaches to memory. The material basis of memory. Journal of Verbal Learning \& Verbal Behavior, 1963, 2, 22-33.

RICCIO D C. HODGES, L A.. \& RANDALL P." K. Retrograde amnesia produced by hypothermia in rats. Journa of Comparative \& Physiological Psychology, 1968, 66, 618-622.

RICCIO, D. C \& STIKES, E. R. Persistent but modifiable retrograde amnesia produced by hypothermia. Physiology \& Behavior, 1969, 4, 649-652. 